\title{
Synergistic effect of certain natural permeabilizers with antimicrobial agents on outer membrane of some multidrug Gram- negative pathogenic bacteria.
}

\author{
${ }^{1}$ Hala A.Farrag; ${ }^{2}$ Nagwa Abdallah; ${ }^{1}$ Mona M. K. Shehata; ${ }^{1}$ Ebthag M. Awad \\ ${ }^{1}$ National Center for Radiation Reserch \& Technology - Egyptian Atomic Energy Authority. \\ ${ }^{2}$ Faculty of Science- Ain Shams University.
}

\begin{abstract}
Infections caused by resistant pathogens result in significant morbidity and mortality and contribute to rising healthcare cost worldwide. The major mechanisms of resistance are permeability barrier of the outer membrane of Gram- negative bacteria as it slows down antibiotic entry into the periplasm. One approach to the restoration of antibiotic activity is to administer them in conjunction with non-antibiotic compounds that depress resistance mechanism. The present study aimed to study the effect of gallic acid, thymol, chitosan, sorbic acid, and EDTA on outer membrane permeability of irradiated and non-irradiated strains to enhance the activity of different antibiotics against multidrug resistance microorganisms. The plasmid profile analysis of some selected strains before and after irradiation was also determined. Various resistance rates were recorded for the tested antimicrobial agents. Percentage resistance of all the tested Gram-negative isolates to different beta-lactam antibiotics exceeded $50 \%$ in case of piperacillin $(84.85 \%)$,cefoperazone / sulbactam (63.64\%), cefoxitin (60.61\%) while showed $(100 \%)$ resistance in case of erythromycin.
\end{abstract}

Keywords: Gram- negative bacteria, outer membrane, natural permeabilizers, gamma radiation

\section{Introduction:}

Bacterial resistance to antimicrobial agents is a global problem, affecting both industrialized and resource-poor countries. Such resistance increases the difficulty of treating both community and hospital-acquired infections, with resulting effect on morbidity, mortality, and economic cost (Shears, 2008). Bacterial resistance is closely associated with the use of antimicrobial agents in clinical practice. Prolonged therapy with antibiotics can lead to the development of resistance in a microorganism that initially is sensitive to antibiotics, but later it can adapt gradually and develop resistance to antibiotics. Over the years, the continued use of various antibacterial/antimicrobial agents has led microorganisms to develop resistance mechanisms, which are the cause of resistance to one or more drugs (multidrug resistance) (MDR) (Giedraitienė, 2011). The emergence of pathogenic bacteria resistant to most, if not all, currently available antimicrobial agents has become a critical problem in modern medicine, particularly because of the concomitant increase in immunosuppressed patients. In June 2000, the WHO warned that the level of resistance to drugs used to treat common infectious diseases is reaching a crisis point. If world governments do not control infections in order to slow down the development of drug resistance, entire populations could be wiped out by superbugs (Ibrahim et al., 2010). The World Health Organization (WHO) has identified antimicrobial resistance as one of the three most important problems for human health. Some authors have summarized this phenomenon with the word 'ESKAPE', to include the most frequent multidrug resistant microorganisms (MDR): Enterococcus faecium, Staphylococcus aureus, Klebsiella pneumoniae, Acinetobacter baumannii, Pseudomonas aeruginosa and Enterobacter spp. (Bassetti et al., 2011).

Corresponding author: E-mail:Hala_farrag_24@hotmail.com 
The outer membrane of Gram- negative bacteria is a semipermeable barrier to the uptake of most hydrophilic molecules larger than certain size (McPhee et al., 2009). This decrease in penetration is responsible for the intrinsic resistance of Gram-negative bacteria to certain antibiotics. Therefore Gram- negative bacteria tend to have higher intrinsic resistance to most antibiotics than their Gram-positive counterparts due to their restricted permeability (Denyer and Maillard, 2002). Lipopolysaccharides characterize the outer membrane of Gramnegative bacteria. They are the principal component of the outer envelope and carry a net negative charge. They are responsible, sometimes in large part, for the impermeability of these microorganisms to antibiotics (Nikaido, 1996 \& Wiese et al., 1999).

Control of Gram-negative bacteria is hampered by the outer membrane (OM) in the outermost layer of the cells. This layer limits the arsenal of antibiotics that are effective in treating Gram-negative bacterial infections. To improve the efficacy of antibiotics, it is necessary to explore methods which improves diffusion of antibiotics and bypasses the bacterial membrane barrier, which is responsible for the general antibiotic resistance in Gram-negative bacteria. Many compounds have been reported to affect membrane permeability of a diverse range of microorganisms, mainly due to the perturbation of the lipid fraction of the cell membrane as they disintegrate the LPS layer. Also, owing to their lipophilic character, they can increase membrane permeability. Such permeabilizers, as they have been termed, are compounds that weaken the OM, can non-specifically enhance the permeability of bacterial cells to exogenous products, including antimicrobial agents, and may therefore potentiate the antibacterial activity of antibiotics that interact with intracellular targets (Abreu et al., 2013 \&Yap et al., 2014).

\section{Materials and methods:}

Microbial cultures collection: Microbial cultures were isolated from urine, blood, ascitic fluid, wound (pus), sputum, throat and stool specimens.

Media used: Media used for isolation and cultivation were carried out on the following agar media (Oxoid-England) according to samples and specimens tested, [nutrient agar (NA), blood agar, MacConkey's no.3, sabouraud dextrose agar, cystine lactose electrolyte deficient Agar, xylose,lysin desoxycholate agar, desoxycholate citrate agar, salmonella shigella agar and tryptic soy broth(TSB)]. Stock culture of all isolates were maintained at $4 C^{0}$ on agar slants and subcultured every two month.

Identification of the isolated pathogenic bacteria: - The identification was carried out by using MicroScan WalkAway- 96 SI System (Dade Behring, Germany) at the National Cancer Institute, Cairo, Egypt.

Antibiotic sensitivity test by disc diffusion method: All bacterial isolates, were subjected to sensitivity test by the disk diffusion technique according to Kirby-Bauer Disk Diffusion Susceptibility test using 24 different antimicrobial agents with different mode of action

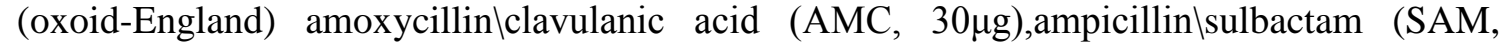

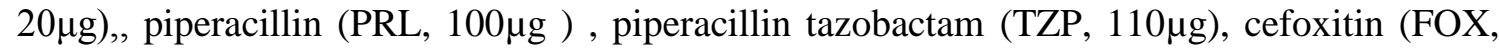

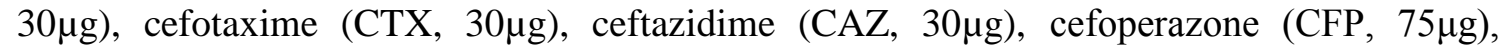

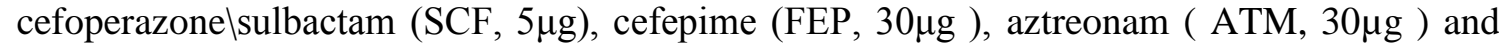

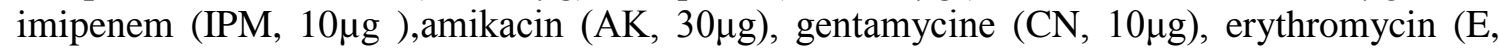

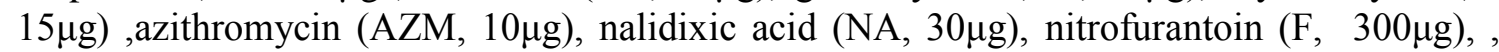
ofloxacin (OFX, $5 \mu \mathrm{g}$ ), colistin sulfate (CT, 30 $\mathrm{g}$ ), sulphamethoxazole trimethoprime (SXT,

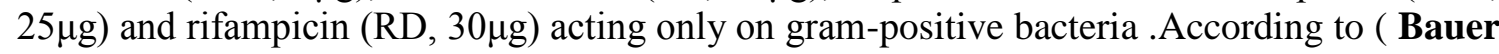
et al., 1966 \& National Committee for Clinical Laboratory Standards (NCCLS, 2010), the diameters of inhibition zones were recorded after 18 to $24 \mathrm{~h}$ at $37^{\circ} \mathrm{C}$, then resistant and susceptible strains were determined. 
Screening for the antibacterial potential of the permeabilizers (Phytochemicals):-This method is used to determine the antibacterial activity of each permeabilizers against four bacterial isolates as described by (Nascimento et al., 2000). The bacterial cultures were grown in NA medium at $37{ }^{\circ} \mathrm{C}$. After overnight incubation, few colonies were inoculated into sterile NB tubes. The tubes were incubated at $37 \pm 1^{\circ} \mathrm{C}$ for $2-4$ hours until visible turbidity were detected .The growth of each microorganism, at a concentration of $10^{6} \mathrm{cell} / \mathrm{s} / \mathrm{mL}$, was inoculated on the surface of NA plates. Subsequently, filter paper discs (6 $\mathrm{mm}$ in diameter) saturated either with extract or phytochemicals $(50 \mu \mathrm{L})$ were placed on surface of each inoculated plate. The plates were incubated at $37^{\circ} \mathrm{C}$ for $24 \mathrm{~h}$.

Effect of some permeabilizers on antimicrobial susceptibility of pathogenic microorganisms: This test was carried out to investigate the effect of some permeabilizers [Gallic acid, Thymol, Sorbic acid, and Chitosan) to increase the susceptibility of selected highly resistant pathogenic bacterial strains to different antibiotics as described by (Ayres $\boldsymbol{e t}$ al., 1999 \& Denny et al., 2003). Twelve different antimicrobial agents were evaluated for synergism assay: Cefoperazone (CFP) $(75 \mu \mathrm{g})$,ceftazidime (CAZ) $(30 \mu \mathrm{g})$, aztreonam (ATM) $(30 \mu \mathrm{g})$, piperacillin (PRL) $(100 \mu \mathrm{g})$, erythromycin (E) $(10 \mathrm{mg})$, azithromycin (AZM) $(15 \mu \mathrm{g}$ ), gentamycin $(\mathrm{CN})(10 \mu \mathrm{g})$, nitrfurantoin $(\mathrm{F})(300 \mu \mathrm{g})$, novobiocin $(\mathrm{NV})(30 \mu \mathrm{g})$ and nalidixic acid (NA) $(30 \mu \mathrm{g})$ For non-beta lactamase producer organisms. Permeabilizer solutions (10 $\mathrm{ml}$ ) of varying concentrations were mixed with a $10 \mathrm{ml}$ volume of nutrient double strength agar. The cell suspension $(0.25 \mathrm{ml})$ was pipetted onto the surface of each plate and spread evenly with a dry sterile swab. The inoculated plates were allowed to dry for $1 \mathrm{~h}$, then antibiotic discs were placed onto the agar surface and the plates were left for $1 \mathrm{~h}$ at $20^{\circ} \mathrm{C}$ for diffusion to occur. The plates were incubated at $37{ }^{\circ} \mathrm{C}$ for $24 \mathrm{hrs}$. and the zones of inhibition were measured.

Determination of Zeta Potential:-Zeta potential experiments were performed according to (Monte et al., 2014). The overnight cultures of $E$. coli was centrifuged at $3777 \mathrm{~g}$ for $10 \mathrm{~min}$ and washed twice with sterile water. Cells suspensions (at a final concentration of $10^{9}$ cells $/ \mathrm{mL}$ ), prepared in sterile tap water, suspension of E. coli was incubated with permeabilizers (gallic acid, thymol and chitosan) for $30 \mathrm{~min}$ at $30 \pm 3^{\circ} \mathrm{C}$. Cells suspensions without permeabilizers were used as control. The zeta potential experiments were performed using a Zeta potential/particle sizer instrument (PSS.NICOMP particle sizing systems, Santa Barbara, California, USA). All experiments were carried out in triplicate at room temperature and were repeated at least at three different occasions.

Effect of in-vitro gamma irradiation on the multi-drug resistant identified strains: Each tested bacterial strains was inoculated in $20 \mathrm{ml}(\mathrm{NB})$ and incubated at $37 \mathrm{C}^{0}$ for 24 hours. The culture obtained was divided under sterile conditions into $2 \mathrm{ml}$ aliquots in 2 groups. One of them exposed to gamma radiation dose level of $24.4 \mathrm{~Gy}$ and the second group remained as a control. Both groups of microorganisms were subjected to:

Permeability assay (Bacteriolysis assay):-.The bacteriolytic effect was assayed on Nunclon microtitre plates (Nunc) by measuring the OD405 of bacterial cultures according to (Helander et al., 1997 \& Alakomi et al., 2003). First, the bacteria were grown to 0.5 at OD630, then cells were deposited by centrifugation $(1000 \mathrm{~g})$ for $10 \mathrm{~min}$ at room temperature and resuspended in a similar volume of $10 \mathrm{mM}$ HEPES/50 $\mathrm{mM} \mathrm{NaCl}$. This suspension was divided into two portions, one of which was supplemented with permeabilizers .The suspensions were incubated at room temperature for $10 \mathrm{~min}$, centrifuged and cells resuspended in the buffer without permeabilizer. Aliquots $\left(10^{8}\right.$ cells in $100 \mu$ l) in quadruplicate were then pipetted into microtitre wells, which already contained appropriate amounts of lysozyme $\left(10 \mu \mathrm{gml}^{-1}\right)$, SDS $(0.05$ and $0.1 \%)$, Triton X-100 (0.1 and $\left.1.0 \%\right)$ or buffer only, and the OD405 was monitored. 
Plasmid analysis of some multi-drug resistant bacterial isolates before and after in-vitro gamma irradiation:- The isolation of plasmid from three multi-drug resistant Gramnegative selected strains Escherichia coli (no.27) and Pseudomonas aeruginosa (no. 48 ) was carried out by the high pure plasmid isolation kit , which includes the following components:Resuspension solution, RNase A (dry powder), Lysis solution, Neutralization solution, Wash solution, Elution buffer, high pure filter tubes and collection tubes.

Agarose gel electrophoresis for isolation of plasmid DNA: Electrophoresis of plasmid DNA was done on horizontal gel apparatus. Agarose (1.0\%) in 1X TBE buffer was prepared. Ten microliters of plasmid DNA and $2 \mu \mathrm{l}$ of loading buffer were mixed well and loaded into the gel containing $10 \mu \mathrm{l}$ ethidium bromide $(1 \mu \mathrm{g} / \mathrm{ml}$ in water). The electrophoresis was conducted for $90-120 \mathrm{~min}$ at constant voltage $75 \mathrm{v}$. . The gel was examined on transilluminator at wave length $312 \mathrm{~nm}$. Photography was carried out by a Polaroid camera sp 34 with specific Polaroid film No 667.

\section{Results and Discussion:}

\subsection{Results:}

In this study as represented in Table (1), out of all positive cases of microbial growth, 81 isolates were collected from them, 66 isolates were Gram- negative bacilli $(81.48 \%), 13$ isolates were Gram- positive cocci $(16.05 \%)$ and 2 isolates were yeast $(2.47 \%)$ isolated out of 105 clinical samples and specimens. The obtained results showed that, 31 urine samples were collected ,pathogenic microorganisms were isolated from 23 samples as (30.86\%), out of 30 ascitic fluid samples, 19 samples were positive for pathogenic microorganism representing $(23.46 \%)$,all collected blood samples and wound (pus) swabs were positive cases representing $(22.22 \% \& 11.11 \%)$ of total positive cases, five pathogenic isolates were obtained from sputum out of 7 samples as $(6.17 \%)$ of total positive cases, seven throat swabs were collected, 4 were positive as (4.94\%) and only 3 stool specimens gave only one positive specimen.

Table (1): Number and frequency of total microbial isolates from different samples and specimens.

\begin{tabular}{|c|c|c|c|c|c|c|c|c|}
\hline \multirow[b]{2}{*}{$\begin{array}{c}\text { Type of } \\
\text { sample or } \\
\text { specimens }\end{array}$} & \multirow[b]{2}{*}{$\begin{array}{c}\text { Total } \\
\text { no. of } \\
\text { isolates }\end{array}$} & \multirow[b]{2}{*}{$\begin{array}{c}\text { Frequency } \\
(\%)\end{array}$} & \multicolumn{4}{|c|}{ Total no. of bacterial isolates } & \multirow[b]{2}{*}{$\begin{array}{l}\text { Total no. } \\
\text { of yeast }\end{array}$} & \multirow[b]{2}{*}{$\begin{array}{c}\text { Frequency } \\
(\%)\end{array}$} \\
\hline & & & $\begin{array}{c}\text { Gram - } \\
\text { negative } \\
\text { bacilli }\end{array}$ & $\begin{array}{c}\text { frequency } \\
(\%)\end{array}$ & $\begin{array}{l}\text { Gram- } \\
\text { positive } \\
\text { cocci }\end{array}$ & $\begin{array}{c}\text { frequency } \\
(\%)\end{array}$ & & \\
\hline $\begin{array}{l}\text { *Urine } \\
\text { samples }\end{array}$ & 25 & 30.86 & 21 & 84.00 & 2 & 8.00 & 2 & 8.00 \\
\hline $\begin{array}{c}\text { Ascitic } \\
\text { fluid } \\
\text { samples }\end{array}$ & 19 & 23.46 & 18 & 94.74 & 2 & 5.56 & & \\
\hline $\begin{array}{c}\text { blood } \\
\text { samples }\end{array}$ & 18 & 22.22 & 11 & 61.11 & 7 & 38.89 & & \\
\hline $\begin{array}{c}\text { Wound } \\
\text { (Pus) swabs }\end{array}$ & 9 & 11.11 & 8 & 88.89 & 1 & 11.11 & & \\
\hline $\begin{array}{l}\text { Sputum } \\
\text { samples }\end{array}$ & 5 & 6.17 & 5 & 100 & & & & \\
\hline $\begin{array}{l}\text { Throat } \\
\text { swabs }\end{array}$ & 4 & 4.94 & 2 & 50 & 2 & 50 & & \\
\hline $\begin{array}{c}\text { Stool } \\
\text { specimens }\end{array}$ & 1 & 1.23 & 1 & $100 \%$ & & & & \\
\hline Total & 81 & 100 & 66 & 81.48 & 13 & 16.05 & 2 & 2.47 \\
\hline
\end{tabular}


*Two samples were mixed with Gram- negative bacilli and yeast.

Identification of pathogenic bacteria from different clinical samples and specimens: All bacterial isolates were identified on the basis of their morphological and biochemical characteristics. Then, the identification was confirmed by using the MicroScan WalkAway-96 SI System (Dade Behring, Germany) at the National Cancer Institute, Cairo, Egypt. Identification was carried out for all strains isolated before radiotherapy (RT). The bacterial isolates were isolated from different sources out of 105 patients revealed that, the isolation of 16 species of pathogenic bacteria belonging to 8 genera, these genera were Escherichia, Acinetobacter, Pseudomonas, Klebsiella, Enterobacter, Proteus, Citrobacter, and Staphylococcus. They represented 30 (37.97\%), 13 (16.46\%), 9 (11.39\%), 6 (7.59\%), 4 $(5.06 \%), 3(3.80 \%), 1(1.27 \%)$, and $13(16.46 \%)$ out of the total bacterial isolates respectively.

Antimicrobial sensitivity test for all pathogenic Gram- negative bacterial isolates to different antimicrobial agents: The frequencies of resistant against different antibiotics by mode of action were determined as shown in fig (1a, 1b, and1c). The percentage of antibiotic resistance against Gram- negative bacterial isolates showed completely resistance to erythromycin E (100\%), followed by novobiocin NV (90.91\%), piperacillin PRL (84.85\%), then cefoperazone CFP (83.33\%), ampicillin sulbactam SAM and cefotaxime CTX showed the same percentage of antibiotic resistance $(74.24 \%)$ to bacterial isolates. While Gram- negative bacterial isolates were less resistant to amikacin AK (34.85), colistin sulfate (CT) (30.30\%), meropenem MEM (10.61\%), finally imipenem IPM (6.06\%).

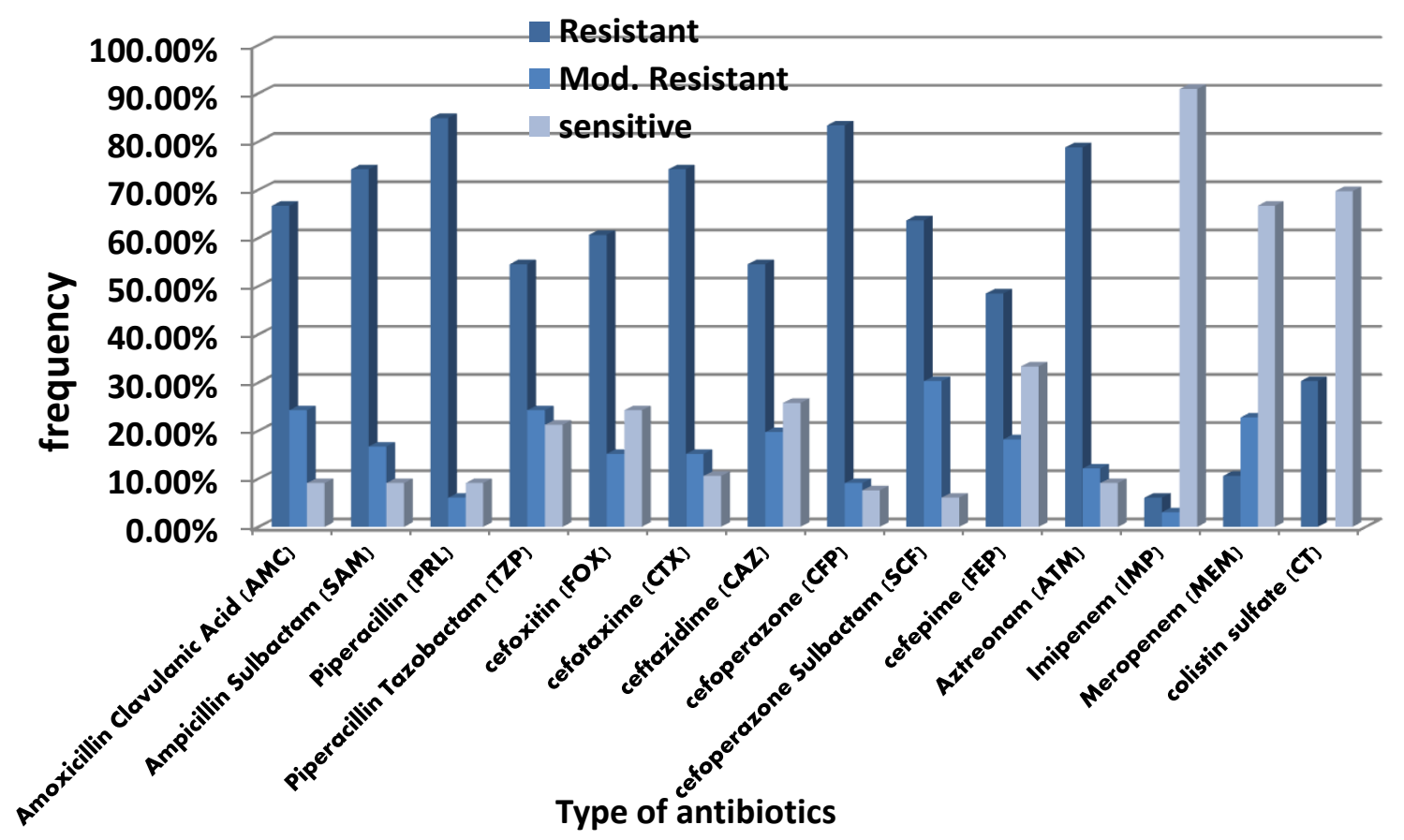

Fig (1a): sensitivity of isolated gram-negative bacilli to antibiotics which acts on the inhibition of cell wall synthesis and cell membrane... 

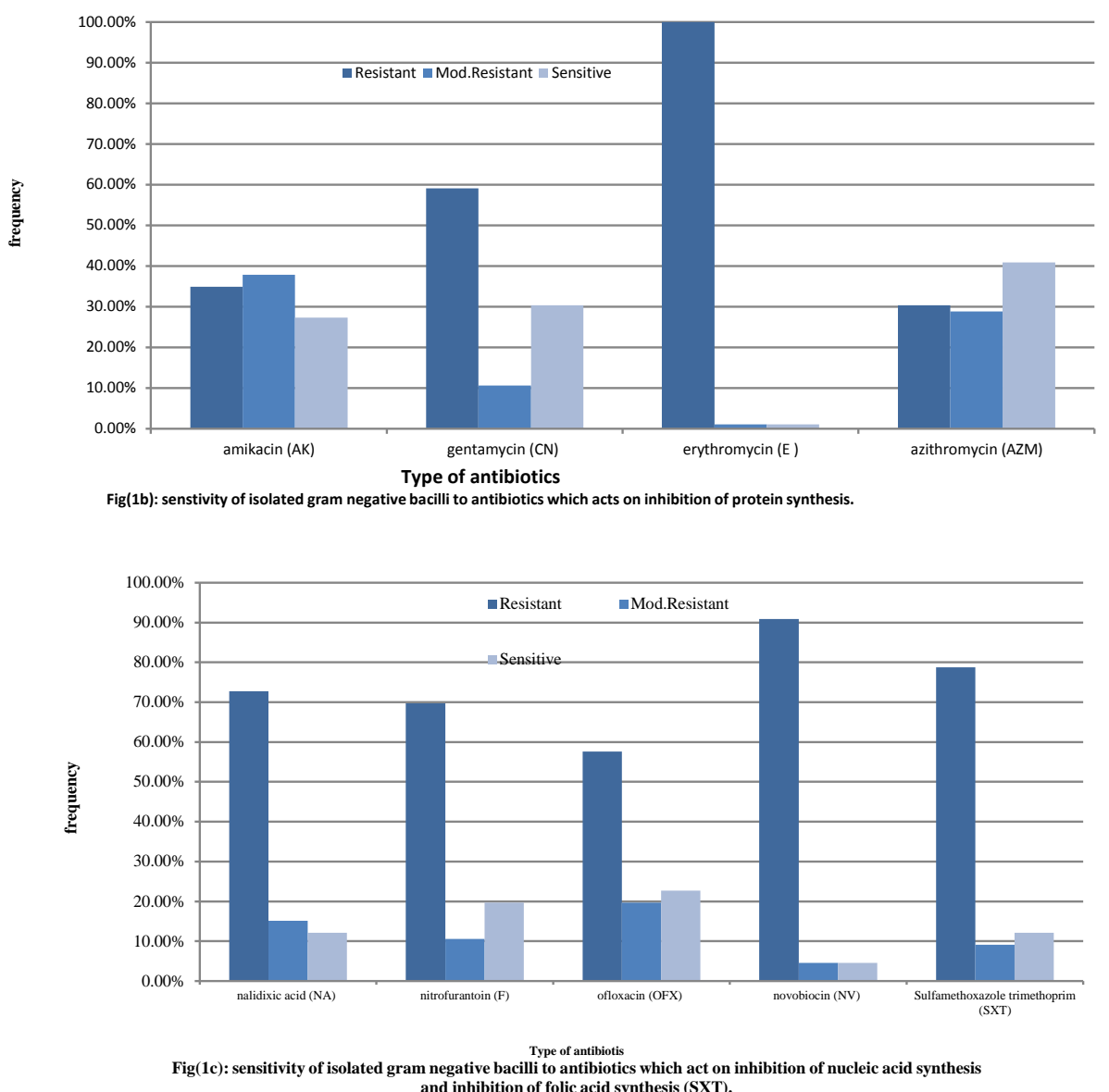

Evaluation of antibacterial potential of phytochemicals (permeabilizers): It was clear that, Gram- negative bacterial isolates had different susceptibility to phytochemicals. E. coli, which is already known to be multiresistant to drugs, was also resistant to the phytochemicals tested. It was susceptible only to sorbic acid at $10 \mathrm{mM}$. On the other hand, A. baumann and $P$. aeruginosa, which that also resistant to different antibiotics, there growth only inhibited by chitosan at $250 \mathrm{ppm}$. While, E. cloacae showed the highest susceptibility to phytochemicals than those of resistant species, it was susceptible to gallic acid at $700 \mu \mathrm{g} / \mathrm{ml}$, ellagic acid at 50 $\mu \mathrm{M}$, thymol at $600 \mu \mathrm{g} / \mathrm{ml}$, and sorbic acid at $10 \mathrm{mM}$. The selection of the tested permeabilizers concentrations based on no antibacterial activity with the tested microorganism. Effect of some permeabilizers on antimicrobial susceptibility of pathogenic microorganisms:-The results in this study showed that, the positive effect of permeabilizers in combination with different classes of antibiotics against selected bacterial isolates ; as most of permeabilizers changed the susceptibility of selected bacterial isolates from being completely resistance to moderate resistance or sensitive are shown in fig 
$(2 \mathrm{a}, 2 \mathrm{~b}$, and $2 \mathrm{c})$.

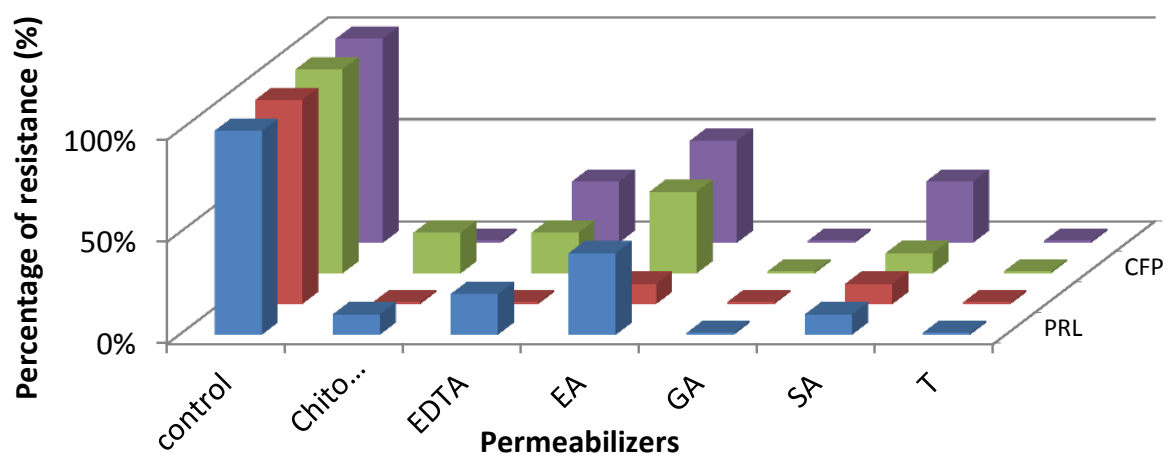

Fig(2-a):synergistic effect of permeabilizers with antibiotics which acts on inhibition of cell wall on bacterial susceptibility pattern of resistance.
EDTA: Ethylene Diamine Tetra Acetic Acid PRL:Piperacillin
EA: Ellagic acid
GA: Gallic acid
CFP: Cefoperazone
SA: Sorbic acid
ATM: Aztreonam

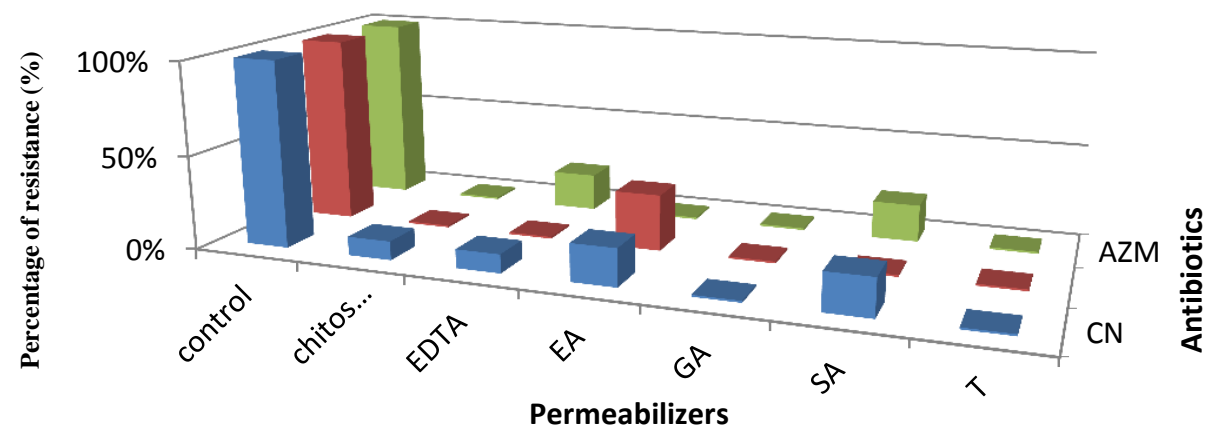

Fig(2-b):synergistic effect of permeabilizers with antibiotics which acts on inhibition of protein synthesis on bacterial susceptibility pattern of resistance
EDTA: Ethylene Diamine Tetra Acetic Acid
EA: Ellagic acid
GA: Gallic acid
SA: Sorbic acid
T: Thymol CN: Gentamycin

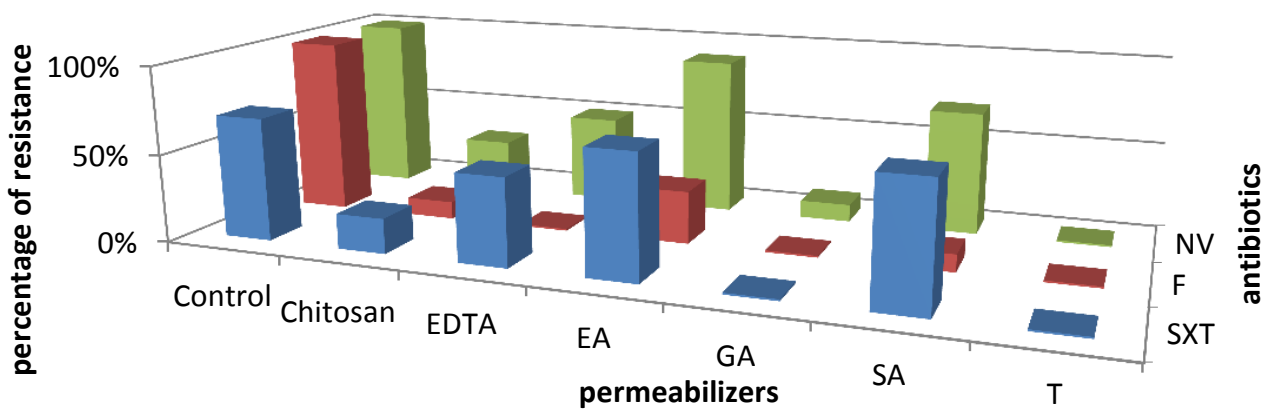

Fig(2-c):synergistic effect of permeabilizers with antibiotics which acts on inhibition of nucleic acid synthesis and inhibition of folic acid synthesis (SXT) on bacterial susceptibility pattern of resistance
EDTA: Ethylene Diamine Tetra Acetic Acid
EA: Ellagic acid
GA: Gallic acid
SA: Sorbic acid
T:Thymol 
Determination of Zeta Potential: The surface charge of the cells is often determined as its zeta potential, which is measured from the mobility of cells in the presence of an electrical field under well-known conditions ( $\mathrm{pH}$ and salt concentrations). At physiologic conditions, most of the microorganisms are negatively charged due to the presence of anionic groups, such as carboxyl and phosphate, in their membranes. The bacterial E. coli strain presents a negative surface charge: $-19.0 \mathrm{mV}$. After exposure to permeabilizers, changes in the surface charge of cells to less negative values were verified. The first one was able to make the membrane surface to become $-14.0 \mathrm{mV}$, while the exposure to thymol changed the surface charge of cells to less negative values $-10.0 \mathrm{mV}$. While the interaction between bacteria and chitosan change the surface charge of cells to $-17.0 \mathrm{mV}$.

Permeability assay for non-beta lactamase isolates: - Increased permeability of the $\mathrm{OM}$ is also manifested as an increased susceptibility to the bacteriolytic action of detergents and to cell-wall degrading action of lysozyme. The test species were subjected to treatments with gallic acid and thymol and subsequently to the detergents SDS or Triton X-100 or to lysozyme before and after exposure to in-vitro gamma irradiation. The significant lysis by Triton X-100 or by lysozyme did not occur in control cells before and after gamma irradiation, whereas SDS (anionic detergent probe) itself some-what had slight lytic effect on the control cells before and after exposure to in-vitro gamma irradiation. In this experiment, gallic acid and thymol caused no sensitization to lysozyme in $P$. aeruginosa. A marked lysis promoting effect was observed in $P$. aeruginosa in the presence of gallic acid and thymol at Triton X-100 (1\%) and both concentration of SDS tested. Lysozyme exhibited a weak lysis in the gallic acid treated culture of $E$. coli, whereas culture treated with thymol remained unaffected. The exposure to gallic acid sensitized E. coli to great extend to SDS and Triton X100 at both concentration tested. While with thymol caused slight sensitization in the Triton X-100 $(0.1 \%)$ treated culture, however strongly sensitized E. coli culture to Triton X-100 $(1 \%)$ and both concentration of SDS. There were no significant changes in all of the experiment results after exposure to in-vitro gamma irradiation than before.

Plasmid DNA profile analysis of some isolated bacterial strains before and after in-vitro gamma irradiation: The plasmid from two highly antibiotic resistant tested strains of Pseudomonas aeruginosa (no.4^), and Escherichia coli (no.27) were extracted and analyzed in agarose gel for detection of any changes before \& after irradiation and also after treatment with permeabilizers in their plasmid profiles (fig. $\left({ }^{r}\right)$ ). The plasmid analysis of Pseudomonas aeruginosa $(P s .4 \wedge)$ before any kind of treatment and after treatment with either irradiation or permeabilizer (Lane $1 \& 2 \& 3$ ) showed a band with the same molecular weight (4000 bp) before irradiation and after treatment with gallic acid, and (3643bp) after irradiation with difference in $\mathrm{Rf}$ and amount after gamma irradiation, but no clear difference observed after treatment with gallic acid. The plasmid analysis of Escherichia coli (E. 27) showed one band with molecular weight (3714) changed to (3400) after exposure to gamma irradiation, also changing occur in its RF value and amount before and after irradiation. But there was no clear change in molecular weight, Rf and amount in this plasmid analysis after treatment with thymol. 


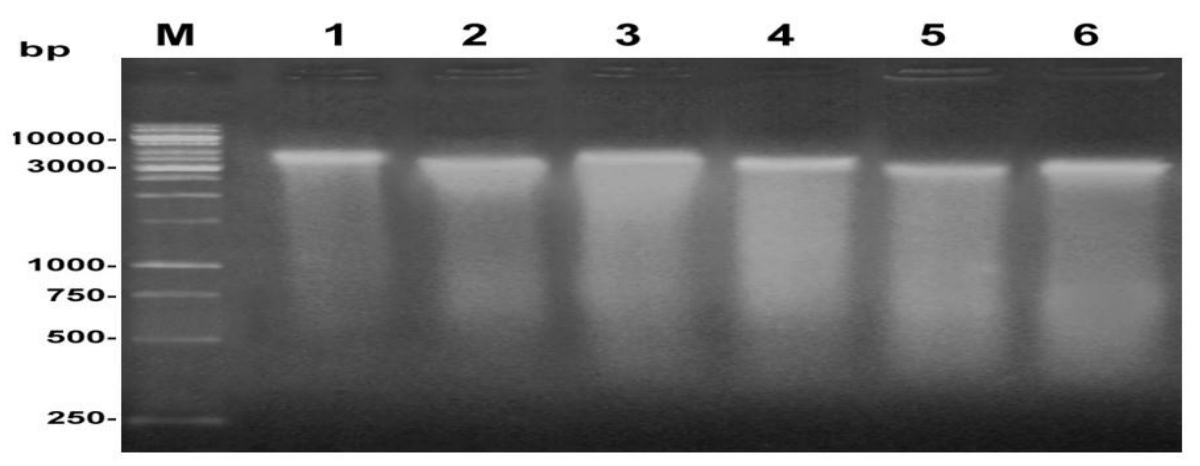

Fig $(\stackrel{\sim}{)}$ ): Agarose gel electrophoresis of extracted plasmids DNA. Lanes: M, mol. wt marker (GeneRular ${ }^{\mathrm{TM}} 1 \mathrm{~Kb}$ DNA Ladder with molecular weight ranged from 250-10000bp ladder, Thermoscientific); lanes1\&2\&3 Pseudomonas aeruginosa isolate $\left(P s .4^{\wedge}\right)$ before, after irradiation, and after treatment with permeabilizer respectively and lanes $4 \& 5 \& 6$ Escherichia coli isolate (E. 27) before, after irradiation, and after treatment with permeabilizer respectively.

\subsection{Discussion}

Infections caused by resistant pathogens result in significant morbidity and mortality, and contribute to rising healthcare cost worldwide. In spite of the availability of new antibiotics, emerging antimicrobial resistance has become an increasing problem in many pathogens throughout the world and rapid detection in clinical laboratories is essential for the prompt recognition of antimicrobial resistant organisms. Nosocomial infections are mainly caused by Gram- negative bacteria, due to intrinsic and acquired capabilities to develop resistance to antimicrobial agents; they are difficult to treat (Vinodhini et al., 2014). The results obtained from this study revealed that, prevalence of microbial infection was in the order of urinary tract infections (UTIs) > ascitic fluid infections (AFIs) > blood stream infections (BSIs) > both respiratory tract infections (RTIs) and wound infections (puss swabs) > stool infections, and Gram-negative bacilli were much more common than Gram-positive cocci, which is in a good agreement with the results recorded by Khalili et al., (2012).Also Sievert et al., (2013) found that, (70\%) of all Gram-negative pathogens causing healthcare-associated infections. Gram-negative bacteria are common causes of intra-abdominal infections (IAIs), UTIs, nosocomial pneumonia, and bacteremia. This results revealed that, E. coli was found to be the most frequent pathogen within all kind of infections followed by Acinetobacter , Pseudomonas, Klebsiella, Enterobacter. This finding is in harmony with Sievert et al., (2013) who reported that, E. coli, Pseudomonas aeruginosa, and Klebsiella pneumoniae are important pathogens in the hospital setting, accounting for (27\%) of all Gram-negative bacterial pathogens. The tested isolates showed high resistance to $\beta$-lactam antibiotics and non-beta lactam antibiotics (aminoglycosides, macrolides and quinolones), while being more sensitive to amikacin, colistin sulfate, meropenem and imipenem. The results agree with those got by Zaid, (2001). Also Singh et al.,(2014 ) stated that ,among Gram-negative bacteria, members of Enterobacteriaceae showed more resistance to ampicillin (91.7\%), amoxiclav $(86.5 \%)$, and gentamicin $(60.9 \%)$, whereas for imipenem and meropenem a comparatively lower rate of resistance of $(0.93 \%)$ and $(12.6 \%)$, respectively. Natural products of various origin can alter the effect of antibiotics, be it increasing or reducing the antibiotic activity. The association between natural products and synthetic drugs has been studied in several works 
and the results are relevant and promising (Veras et al., 2013). From the results obtained in this study, gallic acid $(600 \mu \mathrm{g} / \mathrm{ml})$, ellagic acid $(40 \mathrm{Mm})$, thymol $(500 \mu \mathrm{g} / \mathrm{ml})$, chitosan $(100 \mathrm{ppm})$, EDTA $(0.1 \mathrm{mM})$, sorbic acid $(5 \mathrm{mM})$, quercetin $(50 \mu \mathrm{g} / \mathrm{ml})$, epigallocatechin gallate $(50 \mu \mathrm{g} / \mathrm{m})$ had no antibacterial activity on the selected isolates. This finding is in agree with Patra, (2012) who stated that, Permeabilizers themselves may not be bacteriocidal, but they may potentiate the activity of other compounds, thus acting synergistically .In general, antibacterial activity of phenolic acids is stronger against Gram-positive bacteria than Gramnegative bacteria. The outer membrane of Gram-negative bacteria provides them with a hydrophobic surface structure that is able to exclude certain molecules, making them inherently resistant to many antimicrobial agents including phenolic acids. So in this study; we tried to overcome this problem by making combination between natural products and antibiotics to increase their efficiency against bacterial pathogen, which is also recommended by others, Monte et al., (2014) who stated that, the use of dual combinations of antimicrobial drugs with positive in vitro interactions has become an important parameter to potentiate the therapeutic action of antibiotics. These combinations are expected to exert a synergistic effect or to reduce possible adverse side effects. The use of active compounds, such as phytochemicals, in conjunction with antibiotics could avoid the emergence of resistant variants that might otherwise arise during treatment. .The results in this study demonstrate that, gallic acid and thymol is effective OM permeabilizers, as they sensitize Gram-negative bacteria to hydrophobic antibiotics, these antibiotics are generally not useful in treating Gramnegative bacterial infections because they traverse the OM ineffectively. Abreu et al., (2013) explained that, gallic acid has proven to be an efficient permeabilizer, the OM disintegrating activity of gallic acid was suggested to be based on the chelation of divalent cations and to the partial hydrophobicity of this product, which promote the membrane destabilization. This study showed that, thymol had synergistic activity with different classes of antibiotics, resulting in increased activity of antibiotics against Gram- negative bacterial isolates, which is in a good agreement with others, Yap et al., (2014) investigated the effectiveness of the association between beta lactam antibiotics and essential oils against plasmid-conferred multidrug resistant bacteria in vitro. Wagner and Ulrich-Merzenich, (2009) \& Abreu et al., (2012) reported that, thymol act as "membrane permeabilizers" and that way facilitating the penetration of antibiotics into Gram-negative bacteria. Veras et al., (2013) explained that, due to the great number of chemical components, the essential oils do not possess specific target in the cell. The thymol can be effective against the microorganisms through a lipophilic character action on the cellular membrane, causing the dispersion of the chain of polypeptides of the cellular membrane and destabilizing of the permeability of the cell membrane. Sensitization of Gram-negative cells to cell lysis induced by detergents (e.g. sodium dodecyl sulphate [SDS] and Triton X-100) as well as by lysozyme are indications of weakening of the OM (Alakomi et al., 2003). The activity of thymol and gallic acid as membrane permeabilizers is confirmed by permeability assay; whereas both thymol and gallic sensitize selected Gram- negative isolates to Triton X-100, SDS, lysozyme. Nazzaro et al., (2013) \& Helander et al.,(199 $\mathrm{V})$ studied that, thymol has prominent OM disintegrating properties, as indicated by their enhancing effect on LPS release, as well as sensitization to detergents (SDS and lysozyme). Zeta potential measurements demonstrated that after permeabilizers exposure, the cells become less negatively charged, and this hypothesis is supplemented by evidence of weaken OM permeability barrier. The results in this study is in a agreement with Monte $\boldsymbol{e t}$ al.,(2014) who stated that, the interaction between bacteria and phenolic (gallic acid) change the surface charge of cells to less negative values especially for E. coli. Plasmid DNA content is a unique and relatively stable characteristic of most bacteria, and such it has gained importance as an epidemiologic tool. Plasmid from one strain can be distinguished from those of another on basis of their molecular sizes. Plasmid size is expressed as the number of 
kilo base pairs of DNA and is determined electrophoretic nitrogen in agarose gels. Plasmid DNA profile can be used as an epidemiological marker, but in combination with other typing methods and with antibiotic resistance patterns to characterize the circulation of clinical strains and the spread of resistance in these bacteria (El-Sayed et al., 2015). The results obtained in this method revealed that, Pseudomonas aeruginosa had one plasmid band with molecular weight $4000 \mathrm{pb}$, which is in a fair agreement with El- Hady and Samy, (2011).Also Farrag et al., (2002) found that, The plasmid analysis before irradiation for Pseudomonas aeruginosa isolated from urine culture, revealed only one band of M. Wt. > 3,147 bp. In this study, the plasmid analysis of E. coli showed one band with molecular weight of 3714.As Ahmed et al., (2009) stated that, the analysis of plasmid DNA of E. coli revealed that all the strains contained a heterogeneous population of plasmids ranging between $>23.1 \mathrm{~kb}$ to $2.0 \mathrm{~kb}$. In this study a comparison of the plasmid profiles of the tested isolates showed a definite difference in the molecular weight of the plasmid profile analysis before and after exposure to in-vitro gamma irradiation. This may explained by Ezzat $\boldsymbol{e t}$ al., (2014) who stated that, exposure of bacterial cells to ionizing radiation presents an additional stress to the cells which tends to disturb their organization. Nucleic acids, especially DNA, are the primary target for cell damage from ionizing radiation. Gamma radiation induced three types of damage in DNA, single strand breaks, double strand breaks and nucleotide damage which include base damage and damage in the sugar moiety .The base damage is a major component of damage induced by ionizing radiation. Gamma irradiation also affects protein fingerprinting and enzymes. Also Farrag et al., (2014) detected that plasmid profile analysis of tested irradiated E. coli strains showed more extra-plasmid bands and/or difference in molecular weight.

\section{Conclusion:}

Our planet is saturated with antibiotics, which had a major contribution to the selection of resistant strains. Resistance mechanisms are pandemic and create an enormous clinical and financial burden on health care systems worldwide. Plant-based medicines are important therapeutic weapons to cure human diseases, and are of extremely relevance to pharmacology. The concept of antimicrobial synergy is based on the principle that, in combination, the formulation may enhance efficacy, reduce toxicity, decrease adverse side effects, increase bioavailability, lower the dose and reduce the advance of antimicrobial resistance.

\section{Reference:-}

Abreu, A.C.; Borges. A.; Malheiro, J. and Simões, M., Resurgence of the interest in plants as sources of medicines and resistance-modifying agents. Microbial pathogens and strategies for combating them: science, technology and education (A. Méndez-Vilas, Ed.): 1287-1297 (2013).

Abreu, A.C.; McBain, A.J. and Simoes, M., Plants as sources of new antimicrobials and resistance-modifying agents. Nat. Prod. Rep., 29: 1007-1021 (2012). 
Ahmed, B.; Shakoori, F.R.;. Ali, S.S. and Shakoori. A.R., Antimicrobial resistance pattern and plasmid analysis of Escherichia coli from patients suffering from acute diarrhea in Azad Kashmir, Pakistan. Pakistan J. Zool., 41 (5): 371-380 (2009).

Alakomi, H.L; Saarela, M. and Helander, I.M., Effect of EDTA on Salmonella Typhimurium involves a component not assignable to lipopolysaccharide release. Microbiology, 149: 2015-2021 (2003).

Ayres, H.M., Furr, J.R. and Russell, A.D., Effect of permeabilizers on antibiotic sensitivity of Pseudomonas aeruginosa, Letters in Applied Microbiology, 28: 13-16 (1999).

Bassetti, M.; Ginocchio, F. and Mikulska, M., New Treatment options against Gramnegative organisms. Annual Update in Intensive Care and Emergency Medicine, 1: 501515 (2011).

Bauer, A.W.; Kirby, W.M.M.; Sherris, J.C., and Turck, M., Antibiotic susceptibility testing by a standardized single disk method. Am. J. Clin. Pathol., 45: 493-496 (1966).

Denny, B.; West, P. and Panigrahi, D., Effect of permeabilizers on antimicrobial susceptibility of Stenotrophomonas maltophilia and Acinetobacter spp, J.Microbiol Immunol Infect., 36:72-76 (2003).

Denyer, S.P. and Maillard, J.Y., Cellular impermeability and uptake of biocides and antibiotics in Gram-negative bacteria. Journal of Applied Microbiology Symposium Supplement, 92: 35-45 (2002).

El-Hady, M.A. and Samy, A.A., Molecular Typing of Pseudomonas Species Isolated from Some Cultured Fishes in Egypt. Global Veterinaria, 7(6): 576-580 (2011).

El-Sayed, Z.M.F.;Ahmad K. Al-Ghamdi, A.K.; Esam I. Azhar, E.I.; Nahlaa A. Khalifa, N.A.;Ahmed M. Ashshi, A.M. and Faidaha, H.S., Multidrug resistant bacterial strains and their associated plasmid profile. Life Science Journal, 12(1):1-8 (2015).

Ezzat, S.M.; Abo-State, M.A.; Mahdy, H.M.; Abd El- Shakour, E.H. and ElBahnasawy, M.A., The Effect of ionizing radiation on multi-drug resistant Pseudomonas aeruginosa isolated from aquatic environments in Egypt, British Microbiology Research Journal ,4(8): 856-868 (2014).

Farrag, A.H.; Hussain, A.A.; Salama, M.S. and Mahmoud, R.R., Molecular analysis, antimicrobial resistance and biological properties contributing to pathogenicity in irradiated clinicalisolates associated with urinary tract infection. Az. J.Microbiol., 56: 169-181 (2002).

Farrag A.H., El-Din, A.A; El-Sayed, G.Z. and Kamal, M.M., Adherence of irradiated slime producing bacterial pathogens to biomaterial surface and their antimicrobial susceptibility associated with catheter infection in bladder cancer patients. British Journal of Pharmaceutical Research, 4(13): 1604-1628 (2014). 
Giedraitienè, A.;Vitkauskienè, A.;Naginienè, R. and Pavilonis, A., Antibiotic Resistance Mechanisms of Clinically Important Bacteria. Medicina (Kaunas), 47(3):13746 (2011).

Helander I.M, Alakomi H-L, Latva-Kala K and Koski, P., Polyethyleneimine is an effective permeabilizer of Gram-negative bacteria, Microbiology, 143: 3193-3199 (1997).

Ibrahim, M.K.; Galal, AM.M.; Al-Turk, I.M and Khalid, D., Antibiotic resistance in Gram-negative pathogenic bacteria in hospitals' drain in Al-Madina Al-Munnawara. AlZhrany Journal of Taibah University for Science (JTUSCI) 3: 14-22 (2010).

Khalili, H.; Soltani, R.; Afhami, S.;S. Dashti-Khavidaki, S.; and Alijani, B., Antimicrobial resistance pattern of Gram-negative bacteria of nosocomial origin at a teaching hospital in the Islamic Republic of Iran . EMHJ, 18 (2): 172-177 (2012).

McPhee, J.B.; Tamber, S.; Brazas, M.D.; Lewenza, S. and Hancock, R.E.W., Antibiotic Resistance Due to Reduced Uptake, chapter 9 in D.L. Mayers (ed.), Antimicrobial Drug Resistance,97-110 (2009).

Monte, J.; Abreu, A.C.; Borges, A.; Simões, L.C. and Simões, M., Antimicrobial activity of selected phytochemicals against Escherichia coli and Staphylococcus aureus and their biofilms. Pathogens, (3): 473-498 (2014).

Nascimento, GG.F; Locatelli, J.; Freitas, P.C. and Silva, G.L., Antibacterial activity of plant extracts and phytochemicals on antibiotic resistant bacteria. Brazilian Journal of Microbiology, 31:247-256 (2000).

National committee for clinical laboratory standards (NCCLS), Performance standards for antimicrobial disk susceptibility tests, National Committee for Clinical Laboratory Standards. Villanova, Pa. (2010).

Nazzaro, F.; Fratianni , F.; De Martino, L.; Coppola , R. and De Feo,V., Effect of essential oils on pathogenic bacteria. Pharmaceuticals, 6: 1451-1474 (2013).

Nikaido, H., Outer membrane. In Escherichia coli and Salmonella: Cellular and Molecular Biology 2nd edn, ed. Neidhardt, F.C., Curtiss, R., Ingraham, J.L. et al. pp. 29-47.

Washington, D.C.: American Society for Microbiology (1996).

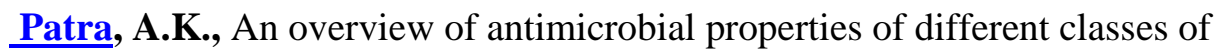
phytochemicals. Dietary Phytochemicals and Microbes., pp 1-32 (2012).

Shears, P., Resistance as a Worldwide Problem, chapter 15 in Bacterial Resistance to Antimicrobials / editors, Richard G. Wax ... [et al.]. 2nd.ed, 363-377 (2008).

Sievert D.M.; Ricks, P.; and Edwards J.R., Antimicrobial-resistant pathogens associated with healthcare-associated infections: summary of data reported to the National Healthcare Safety Network at the Centers for Disease Control and Prevention, 2009-2010. Infect Control Hosp Epidemiol, 34: 1-14 (2013). 
Singh, A.K.; Venkatesh, V.; Singh, R.P. and Singh. M., Bacterial and antimicrobial resistance profile of bloodstream infections: A hospital-based study. Journal of Health and Research, 1 (3):140-144 (2014).

Veras, H.N.H ; Rodrigues, F.F.G; Botelho , M.A.;Irwin R.A. Menezes, I.R.A, Coutinho, H.D.M. and Costa , J.G.M., Enhancement of aminoglycosides and betalactams antibiotic activity by essential oil of Lippia sidoides Cham. and the Thymol. Arabian Journal of Chemistry, 10:1-6 (2013).

VinodhiniI, R.; Moorthy. K.; Palanivel, P.; Punitha. T.; Selvam Saranya, S.; Bhuvaneshwari, M. and Kanimozhi, C., Detection and antimicrobial susceptibility pattern of ESBL producing Gram-negative bacteria, Asian J. Pharm. Res., 7 (11): 243-247 (2014).

Wagner, $\mathbf{H}$. and Ulrich-Merzenich, G., Synergy research: approaching a new generation of phytopharmaceuticals. Phytomedicine, 16(2-3):97-110 (2009). Wiese, A.; Brandenburg, K.; Ulmer, A.J.; Seydel, U. and Muller-Loennies, S., The dual role of lipopolysaccharides as effector and target molecules. Biological Chemistry, 380: 767-784 (1999).

Yap, P.S.; Yiap, B.C.; Ping, H.C. and Lim, S.H., Essential oils, A new horizon in combating bacterial antibiotic resistance. The Open Microbiology Journal, 8: 6-14 (2014).

Zaid, A. M., Studies on $\beta$-lactamases Producing Bacteria Belonging to Genus Pseudomonas. Ph.D. Thesis, Botany Department, Faculty of Science, Zagazig University, Egypt (2001). 


\section{الملخص العربي - n}

تأثثر التأزرى لبعض المنفذات الطبيعية مع المضادات الحيوية على نفاذية الفثاء الخارجي للعزلات البكتيرية الممرضة سالبة الجرام المقاومة للمضادات الميفة الحيوية

ا.د/هالة عبد الله فراج' ـ ا.د/نجوى عبد الله ' ـ ا.م.د/منى محمد كمال كامل شحاتة' ـ ابتهاج محمد عواد'

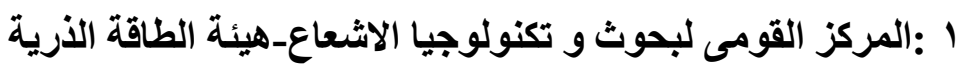

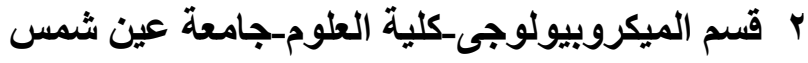

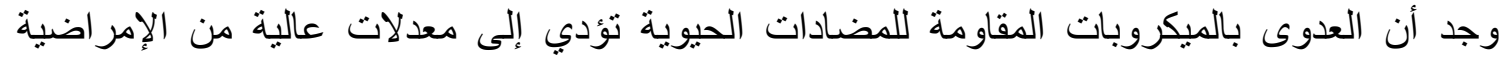

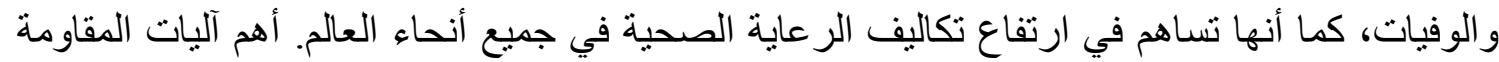

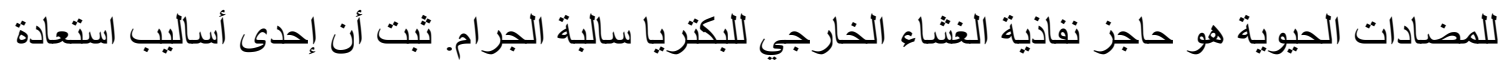

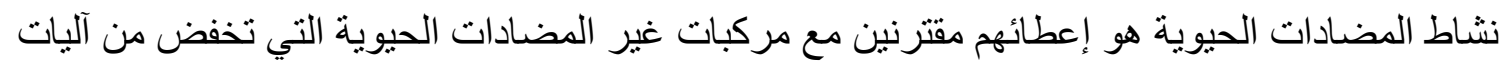

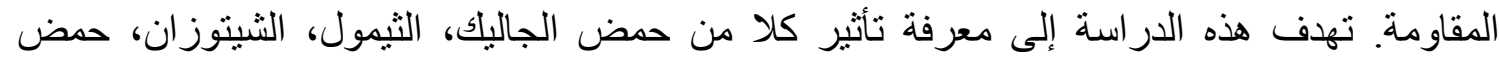

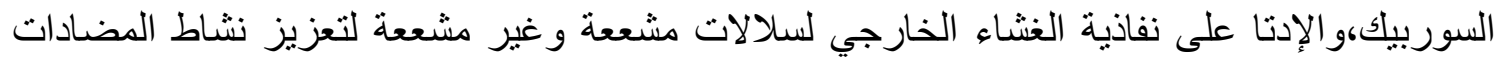

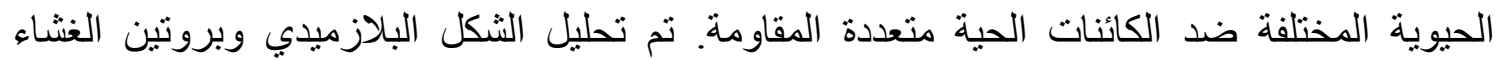

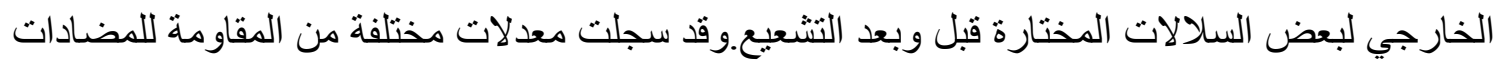

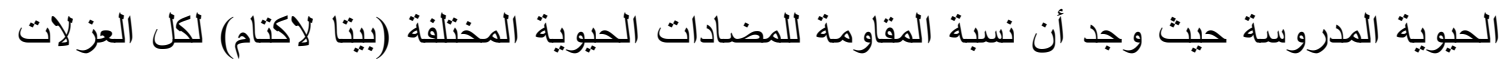

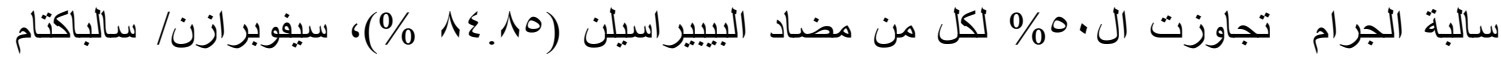

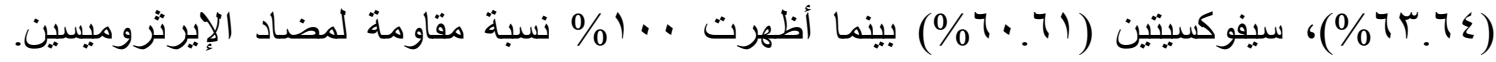

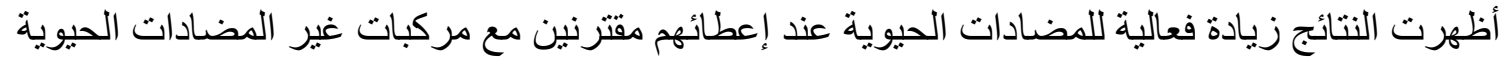

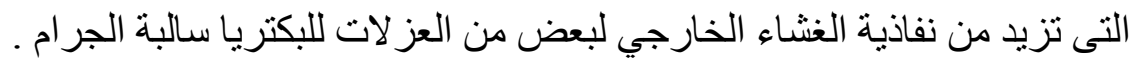

